\title{
Summer Diet of Weddell Seals (Leptonychotes weddelli) in the Eastern and Southern Weddell Sea, Antarctica
}

\author{
Joachim Plötz \\ Alfred-Wegener-Institut für Polar- und Meeresforschung, Columbusstrasse, D-2850 Bremerhaven, Federal Republic of Germany
}

Received 30 September 1985; accepted 20 February 1986

Summary. Stomach and intestine samples from 21 adult Weddell seals were used to study the diet of these seals from the eastern and southern Weddell Sea coast from January to February 1983 and 1985 . Fish occurred in all seals, squid in five, octopods in three and Euphausia crystallorophias in one seal. Pleuragramma antarcticum was the predominant fish in the diet, constituting $61.1 \%$ of otoliths in 1983 samples and $93.8 \%$ in 1985. Aethotaxis mitopteryx, Dissostichus mawsoni, unidentified Trematomus spp. and channichthyids were also recorded. Size and wet weight of $P$. antarcticum were calculated from uneroded otoliths, found in 6 seal stomachs with liquid food pulp, collected during early morning hours in 1985. Size distribution of $P$. antarcticum from individual seals was reasonably constant, ranging between 5.0 and $22.0 \mathrm{~cm} \mathrm{SL}$; adult fish from about 14.0 to $19.0 \mathrm{~cm} \mathrm{SL}$ predominated. $P$. antarcticum in seals from the southern area had a larger median size $(16.5 \mathrm{~cm}$ SL), than those from further east $(15.5 \mathrm{~cm} \mathrm{SL})$. Calculated wet weights of all $P$. antarcticum from individual seal stomachs ranged between 4.7 and $16.9 \mathrm{~kg}$ the mean was $12.8 \mathrm{~kg}$. Comparisons with net-hauls from the southern Gould Bay suggest that Weddell seals feed mainly in deeper water layers $(>400 \mathrm{~m})$ where adult $P$. antarcticum occur at higher densities.

\section{Introduction}

Although the Weddell seal is the best known of the Antarctic seal species, its feeding biology is poorly understood. Weddell seals in general mainly take fish and cephalopods, and only tentative quantitative conclusions are possible at present (Laws 1984). Almost all studies on the diet of Weddell seals have been carried out in the Ross Sea near McMurdo Station and there is a lack of information for the Atlantic- and Indian sector of the Southern Ocean, with the exception of the Scotia Sea (Clarke and MacLeod 1982; Croxall et al. 1985; Lipiński and Woyciechowski 1981). Quantitative data on food intake as well as data on size of dominant prey organisms taken by individual Weddell seals are sparse and urgently required for different areas and seasons, before more realistic assessments of food consumption can be made.

This study is the first report on the summer diet of Weddell seals along the high Antarctic Weddell Sea coast. The eastern and southern parts of this area are characterized by both shallow and deep water zones with grounded or floating ice shelf masses and permanent eroding ice edges. During summer, when the fast ice cover breaks off close to the ice shelf edge, the resting sites of Weddell seals become reduced and the animals are compelled to occupy drifting floes or concentrate in the inlets, where remaining multiyear sea ice provides a permanent habitat. Due to the almost open waters, the hunting range and success of Weddell seals is not influenced by the availability of breathing holes and tide cracks, but probably more by the distribution of sea ice and the distribution and abundance of dominant prey organisms along the ice shelf barrier during the short summer.

\section{Materials and Methods}

Studies on Weddell seals were conducted during the 1983 "ANT I" and 1985 "ANT III" expeditions of the German $R V$ Polarstern. Field work on sea ice was supported by helicopter. Figure 1 shows the sites where seals were collected along the eastern and southern Weddell Sea coast between Atka Bay and Gould Bay. In 1983, a total of 8 adult Weddell seals ( 5 males, 3 females) were taken from early January to the end of February between about $11.00-18.00$ local time (LT). Thirteen adult Weddell seals (6 males, 7 females) were collected in 1985 from the end of January to mid February during early morning hours between $04.00-09.00 \mathrm{LT}$. The state of maturity was determined from standard length of seals after Stirling (1971). Full stomachs were weighed to within $100 \mathrm{~g}$, aboard ship. The $\mathrm{pH}$ of the stomach fluid was determined where possible. Stomach and intestine contents were flushed into separate tubs using sea water. Contents were repeatedly washed to separate hard from soft food items and the latter were then carefully decanted through graded sieves. Hard food items such as fish otoliths, bones, 
eyeballs and cephalopod beaks were retained on the bottom of the tubs and subsequently transferred into black trays. Fish skulls were carefully examined for retained otoliths and the material was sorted and preserved in $70 \%$ ethanol for later analysis. Emptied stomachs were again weighed to determine weight of contents. Parasites from the digestive tracts were also collected.

Fish otoliths from stomachs and intestines were identified to species level where possible, using a reference collection. Body length and weight of the prey fish Pleuragramma antarcticum were calculated as follows: All left sagittal otoliths showing no signs of erosion were selected from 6 stomachs containing liquid food pulp. Maximum length of otoliths was measured to the nearest $0.02 \mathrm{~mm}$, under a binocular microscope. Differentiation between intact and eroded otoliths was done empirically. Otoliths with flattened and broken margins or atypically smooth external structures on the usually crenated medial surface were disregarded. Standard length (SL) of $P$. antarcticum consumed by seals, was calculated by linear regression using the data from fish catches in the same area of investigation (Hubold, personal communication):

$\mathrm{y}($ otolith length, $\mathrm{mm})=0.012 \times(\mathrm{SL}, \mathrm{mm})+0.066 ;(\mathrm{r}=0.98)$
The relationship between standard length and wet weight (WW) of $P$. antarcticum was calculated by exponential regression (Hubold, personal communication):

$\mathrm{WW}(\mathrm{g})=0.00346 \mathrm{SL}^{3.3}(\mathrm{~cm})$

Cephalopods were separated into Octopoda and Decapoda (squid) according to beak structure, after Clarke (1962). Euphausia crystallorophias were identified from the length of maxillipeds. The number of exoskeletons was estimated from subsamples.

\section{Results}

Of the 8 Weddell seals collected in 1983, throughout the day, only 1 had a moderately full stomach, containing fish otoliths, bones and eyeballs. The remaining 7 had small amounts of food remains. Of the 13 seals taken in 1985 , during early morning hours, 6 had stomachs filled with large amounts of liquid food pulp, sometimes con-

Table 1. Frequencies of food items from digestive tracts, and weight of stomach contents from Weddell seals (Leptonychotes weddelli), collected along the eastern and southern Weddell Sea coast during the summer 1983 and 1985

\begin{tabular}{|c|c|c|c|c|c|c|c|c|c|c|c|}
\hline 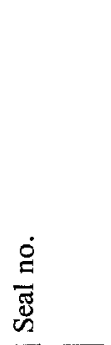 & \multicolumn{6}{|c|}{ Frequency of fish otoliths $(\%)$} & 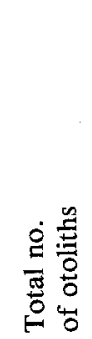 & \multicolumn{2}{|c|}{$\begin{array}{l}\text { Cephalopod } \\
\text { beaks (no.) }\end{array}$} & \multicolumn{2}{|c|}{$\begin{array}{l}\text { Stomach con- } \\
\text { tents }(\mathrm{kg})^{\mathrm{b}}\end{array}$} \\
\hline \multicolumn{12}{|c|}{ Area east (1983) } \\
\hline W1/83 & & & & 86.7 & & 13.3 & 15 & & & & \\
\hline 2 & & & 4.2 & 50.0 & 12.5 & 33.3 & 24 & 6 & 15 & & \\
\hline 3 & & & & 16.7 & & 83.3 & 18 & & & & \\
\hline 4 & 5.9 & & & 67.6 & & 26.5 & 34 & 11 & 3 & & \\
\hline $5^{c}$ & 22.2 & & & 58.3 & & 19.5 & 36 & & & & \\
\hline \multicolumn{12}{|c|}{ Area east (1985) } \\
\hline W1/85 & 99.6 & & & & & 0.4 & 1287 & 6 & & 16.9 & 15.7 \\
\hline 2 & 99.6 & & & & & 0.4 & 948 & 3 & & 9.5 & 13.2 \\
\hline 3 & 89.3 & & & & & 10.7 & 84 & & & & \\
\hline 4 & 99.9 & & & & & 0.1 & 919 & & & 8.1 & 11.2 \\
\hline 5 & 38.6 & 15.9 & & & & 45.5 & 44 & & & & \\
\hline 12 & 84.2 & & & & & 15.8 & 19 & 3 & & & \\
\hline 13 & 19.4 & & & 16.4 & 53.0 & 11.2 & 134 & & 10 & & \\
\hline \multicolumn{12}{|c|}{ Area south (1985) } \\
\hline 6 & 28.6 & & & & & 71.4 & 28 & & & & \\
\hline 7 & 95.6 & & & 0.7 & 0.2 & 3.5 & 1007 & & & 7.6 & 14.8 \\
\hline
\end{tabular}

${ }^{a}$ Lower and upper beaks are included

b Only stomachs with liquid food content are included

${ }^{c}$ Intestine of seal contained ca. 11500 exoskeletons of E. crystallorophias

(n) Total no. of items per prey taxon 
taining almost intact specimens of Pleuragramma antarcticum. The $\mathrm{pH}$ of the stomach fluid ranged between 5.4 and 5.8. These 6 seals were collected immediately after they had hauled out. Of the rest, 3 stomachs were moderately full and 4 only contained food remains. However, all digestive tracts included identifiable fish otoliths. Data on food item frequencies and prey taxa from whole digestive tracts of the collected Weddell seals are summarized in Table 1.

Fish were the major food item of all seals, while squid occurred in 5 seals $(23.8 \%)$ and octopods in 3 seals $(14.3 \%)$. Euphausia crystallorophias was found in the intestine of 1 seal (approx. 11500 individuals). A few crustaceans such as amphipods, fish-parasitic isopods and euphausiids were found usually in full stomachs. As they probably originated from digested fish, they were disregarded.

Identifiable fish species were the midwater nototheniids $P$. antarcticum, Aethotaxis mitopteryx and Dissostichus mawsoni. Other taxa which could be identified were the bottom fish Trematomus spp. and the benthopelagic icefish Channichthyidae. Otoliths of closely related fish groups often show high similarity. Thus, Trematomus could not be determined to species level with certainty, and it is possible that Pagothenia borchgrevinki of the subfamily Trematominae was enumerated as Tre- matomus spp. Furthermore, channichthyids could only tentatively be identified to the genus Pagetopsis, Chionodraco and Cryodraco and are therefore summarized under Channichthyidae.

$P$. antarcticum was the predominant fish taken by Weddell seals. It constituted $61.1 \%$ of all otoliths $(\mathrm{n}=388)$ recorded in 1983 samples and $93.8 \%$ of all otoliths $(\mathrm{n}=6346)$ in 1985 . A. mitopteryx and $D$. mawsoni were represented by only 7 and 3 otoliths in both years. Otoliths of Trematomus spp. comprised $20.6 \%$ in 1983 and $2.8 \%$ in 1985 , while otoliths of the channichthyids were represented by $4.6 \%$ and $1.3 \%$, respectively. Size and weight of prey fish were calculated from uneroded left otoliths of $P$. antarcticum found in the 6 stomachs with liquid food pulp, collected in 1985 . The total number of disregarded, eroded otoliths in these stomachs ranged from 28 to 232 . Figure 2 shows the size distribution of $P$. antarcticum taken by the individual seals. Fish sizes did not have a normal distribution. For this reason median, rather than mean values are calculated. The size distribution of $P$. antarcticum is relatively constant among the 6 seals. The estimated fish sizes range between 5.0 and $22.0 \mathrm{~cm} \mathrm{SL}$. The median length classes taken by individual seals ranged between 15.0 and $16.5 \mathrm{~cm}$ SL. Adult $P$. antarcticum of size classes from about 14.0 to $19.0 \mathrm{~cm} \mathrm{SL}$, including 8 and more individuals per size

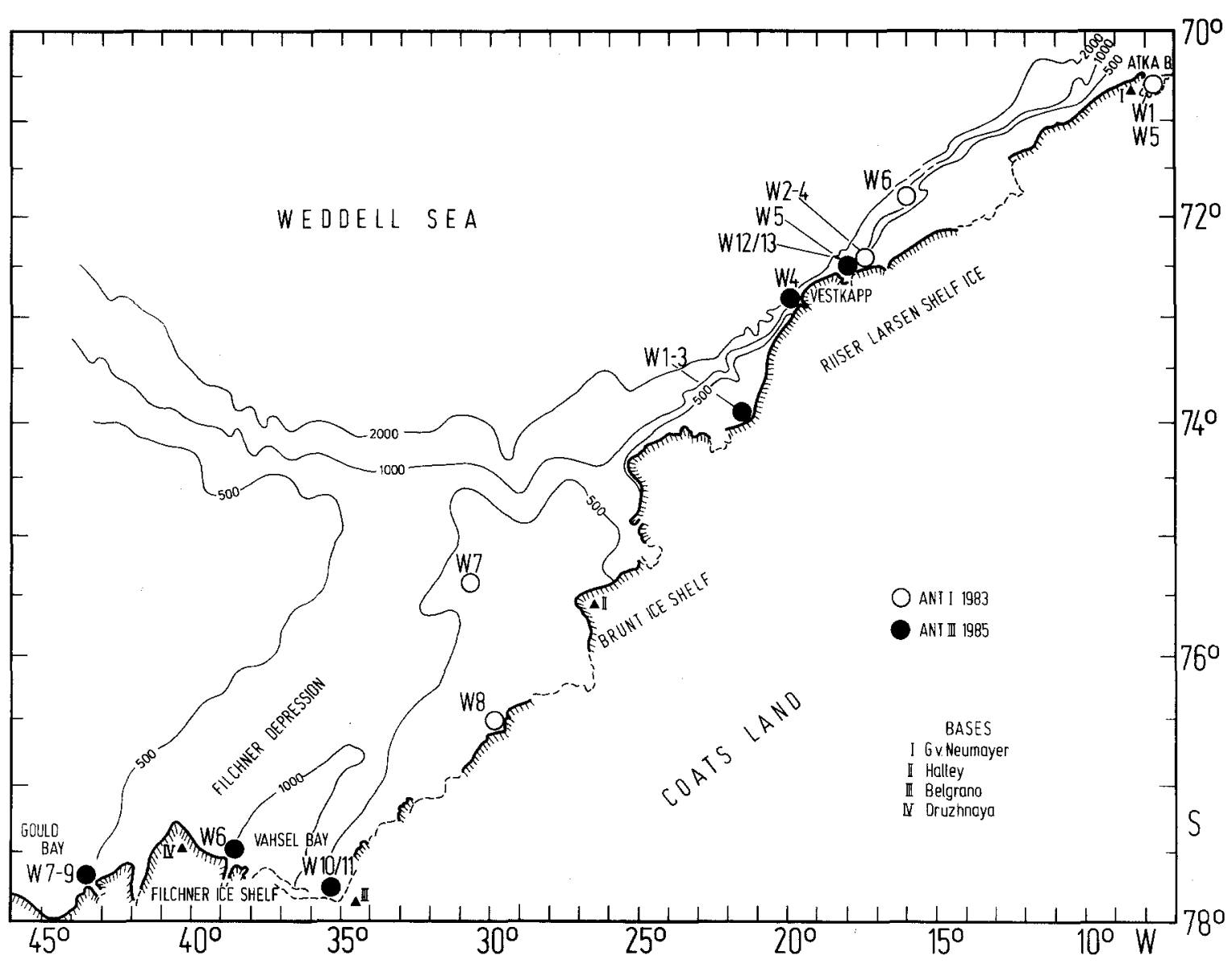

Fig. 1. Investigation area with sites of Weddell seals (Leptonychotes weddelli), collected during the summer 1983 and 1985 

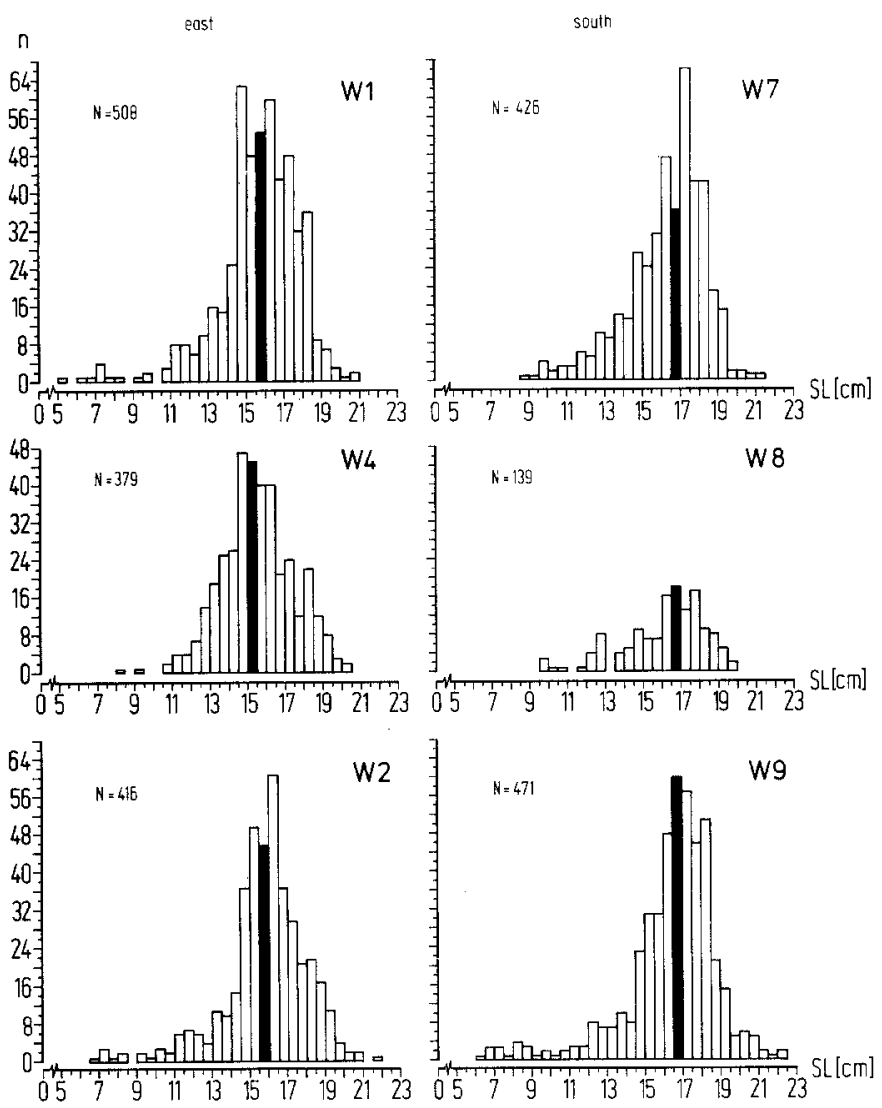

Fig. 2. Length-frequency distribution of Pleuragramma antarcticum taken by individual Weddell seals (Leptonychotes weddelli) from the eastern and southern Weddell Sea coast during the summer 1985. N: number of uneroded left otoliths per seal stomach; $n$ : number of uneroded left otoliths per size class; SL: standard length of fish in $\mathrm{cm}$; Black bar indicates the median size class

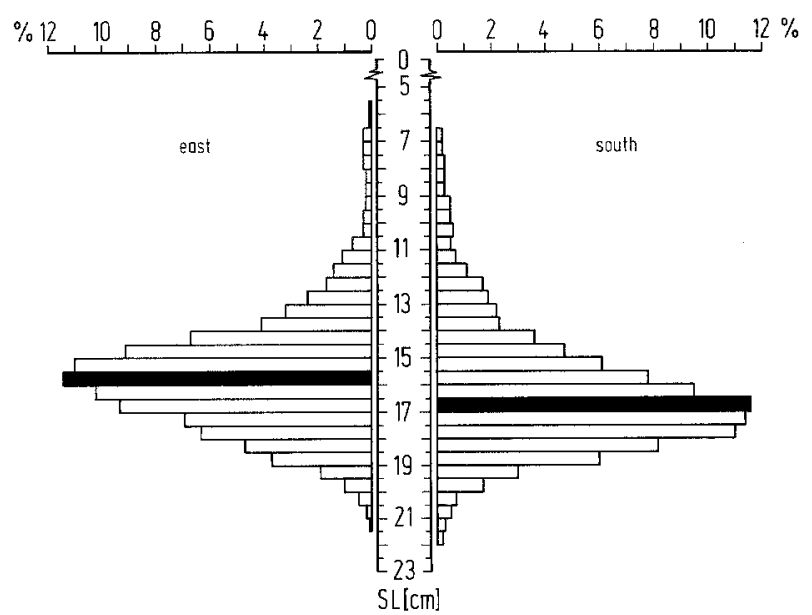

Fig. 3. Comparison of the length-frequency distribution of Pleuragramma antarcticum from the stomachs of 3 Weddell seals (Leptonychotes weddelli) from the eastern and 3 Weddell seals from the southern Weddell Sea coast, collected during the summer 1985. \%: relative number of uneroded left otoliths (east: $n=1303$; south: $n=1036$ ); SL: standard length of fish in $\mathrm{cm}$; size classes were smoothed by running average of three values; black bar indicates the median size class group, predominated. The number of $P$. antarcticum, taken by the individual seals ranged between 139 and 508. The intact appearance of some ingested $P$. antarcticum with standard lengths up to $20 \mathrm{~cm}$ indicated that they had been swallowed whole.

Figure 3 shows a comparison of the relative frequency distributions of calculated standard lengths of $P$. antarcticum from the stomachs of 3 seals each from the eastern and southern areas. Size classes were smoothed by running average of three values. $P$. antarcticum in seals from the southern area had a larger median size $(16.5 \mathrm{~cm}$ SL) than those from further east $(15.5 \mathrm{~cm} \mathrm{SL})$. The difference of $1.0 \mathrm{~cm} \mathrm{SL}$ was found to be highly significant $(P<0.001$; Kolmogoroff-Smirnoff test).

The calculated wet weight of $P$. antarcticum in the 6 stomachs ranged between 4.7 and $16.9 \mathrm{~kg}$ (Table 1); the mean was $12.8 \mathrm{~kg}$. In 5 seals the calculated weight of fish exceeded the recorded weight of the liquid food pulp by 2.4 to $7.2 \mathrm{~kg}$, while in one seal, the calculated weight was $1.2 \mathrm{~kg}$ lower. The calculated weight of all $P$. antarcticum taken by the 6 seals $(n=2339)$ was $76.5 \mathrm{~kg}$. Two thirds $(50.9 \mathrm{~kg})$ of this weight was made up by the fish in the size classes above the median $(16.75-22.0 \mathrm{~cm} \mathrm{SL})$.

Almost all digestive tracts were heavily infested by helminth parasites. Cestodes predominated in the duodenal valve, while the anisakid nematodes Contracaecum osculatum and $C$. radiatum were concentrated in the stomach. Nematode samples, collected in 1983, were examined by Kloeser et al. (in preparation), who reported a maximum infestation intensity of 122640 nematodes in one seal stomach.

\section{Discussion}

Øritsland (1977), in his summary on the diet of Weddell seals, concluded that they take mainly fish $(53 \%)$, followed by cephalopods $(11 \%)$ and other invertebrates $(36 \%)$. As recorded in those studies, bentho-pelagic channichthyids and bentho-demersal nototheniids other than $P$. antarcticum, constituted the main food supply of Weddell seals. The first record of $P$. antarcticum in the diet of Weddell seals was given by DeWitt and Tyler (1960), who found 14 adult fish in one seal from McMurdo Sound. Dearborn (1965) positively identified $P$. antarcticum from 4 of 36 Weddell seal stomachs with food remains, collected at McMurdo Sound during October-April 1958 and 1961. However, fish remains in 34 of these stomachs could not be identified. These may thus also have included $P$. antarcticum. Recent qualitative studies on faecal droppings (scats) suggest that $P$. antarcticum is an important food item for Weddell seals in the Ross Sea (Davis et al. 1982; Castellini et al. 1984). Testa et al. (1985) collected 49 scats in McMurdo Sound during November 1982 and noted that there was a trend toward a high occurrence of $P$. antarcticum in the diet of Weddell seals outside colonies. Furthermore, $P$. antarcticum occurred in 26 stomachs of 28 Weddell seal stom- 
achs with food remains collected in the same area during January 1983.

The present study shows the ubiquitous occurrence of the prey fish $P$. antarcticum in all but three Weddell seals, collected randomly along the ice shelf edge of about $1200 \mathrm{~km}$ from Atka Bay to Gould Bay. The large numbers of $P$. antarcticum and the fairly consistent pattern of size classes taken by individual seals in both the eastern and southern part of the Weddell Sea suggest that fish were encountered in dense aggregations. $A$. mitopte$r y x$ and $D$. mawsoni, unidentified bottom fish Trematomus spp. and bentho-pelagic channichthyids, as well as squid, octopods and crustaceans (E. crystallorophias) formed the lesser part of the food consumed by seals. The rare occurrence of $D$. mawsoni in seal samples from the Weddell Sea coincide with the data of Testa et al. (1985), who pointed out that Antarctic cod in McMurdo Sound do not appear to be an important food source of Weddell seals for more than a limited time in December. Squid and octopods are apparently also less important to seals in the eastern and southern parts of the Weddell Sea, than in lower latitudes such as the Antarctic Peninsula and the South Shetland Islands, where Weddell seals feed more intensively on cephalopods (Bertram 1940; Clarke and McLeod 1982; Lipiński and Woyciechowski 1981). The finding of E. crystallorophias in one seal is of special interest as this is the first direct proof of this species in the diet of Weddell seals, a likelihood which was suggested by Marr (1962), but could not be verified.

Net-hauls with a scientific krill trawl in the Gould Bay (Hubold and Ekau 1985) yielded different size classes of $\boldsymbol{P}$. antarcticum at different sampling depths. The authors reported on the high abundance of fingerlings $(5.0-11.0 \mathrm{~cm} \mathrm{SL})$ in sampling depths between $400 \mathrm{~m}$ and surface, while adult fish of about 13.0 to $22.0 \mathrm{~cm} \mathrm{SL}$ were caught in water depths below 400 and down to $850 \mathrm{~m}$. The pattern of size class distribution at the latter depths is almost identical to that found in the Weddell seals. A shift to larger size classes of $P$. antarcticum in net-hauls from northeast to southwest in the Weddell Sea (Hubold, personal communication) is also distinguishable and even more pronounced in the distribution patterns of $P$. antarcticum from Weddell seals out of this region (Fig. 3).

These observations suggest, that in some areas Weddell seals may have to dive to depths below $400 \mathrm{~m}$ in order to secure adult $P$. antarcticum unless these show some vertical migration. Feeding at these depths appears to be unselective as evident from the almost identical patterns of size class distribution of ingested fish and net catches. Fingerlings which occur at higher densities in upper water layers are underrepresented in the stomachs of seals. The hunting of seals in deeper water corresponds with investigations of Kooyman (1981) who reported that, during the months of October to January Weddell seals in McMurdo Sound commonly dive to $300-400 \mathrm{~m}$ and reach a maximum depth of $600 \mathrm{~m}$, essentially the bottom depth of the water where these inves- tigations were conducted. In the southern Gould Bay and eastern Vestkapp area water depths of about $1000 \mathrm{~m}$ are common close to the ice shelf edge (Fig. 1) and it is possible that seals are able to dive even deeper than reported by Kooyman (1981) in order to gain the more rewarding prey.

The weight of liquid food pulp from 6 selected stomachs was compared with the calculated wet weight of $P$. antarcticum consumed by these seals. The calculated weight was higher with one exception, which suggests that digestion of soft fish flesh is rapid and takes place continuously, commencing at the moment of food intake. Erosion of otoliths and other hard fish remains, however, seems to be slow during feeding as indicated by both the high numbers of uneroded otoliths in the full stomachs and the relatively high $\mathrm{pH}$-values of liquid food pulp (pH 5.4-5.8). The latter could be caused by the large quantities of $P$. antarcticum ingested. It is likely that erosion of hard remains takes place at a more rapid rate during the haul-out period of seals, when digestion of fleshy parts of the fish meal is completed. Otoliths found in intestines and almost empty stomachs were few in number and mostly strongly eroded. Murie and Lavigne (1985), using Atlantic herring (Clupea harengus) as an experimental diet for captive grey seals (Halichoerus grypus), recovered $100 \%$ of ingested otoliths in the stomachs $2.8 \mathrm{~h}$ after feeding and none after $18 \mathrm{~h}$. Within $3-6 \mathrm{~h}$ a large percentage of otoliths were considerably eroded or even completely digested. Taking these findings into account, the high numbers of uneroded $P$. antarcticum otoliths from the 6 Weddell seals which were collected immediately after they had come out of the water suggest that the fish had been consumed recently. In addition, the relatively thick otoliths of $P$. antarcticum are probably more durable than the thin and fragile otoliths of Atlantic herring.

Øritsland (1977) tentatively estimated the average daily food intake for Weddell seals to be $18 \mathrm{~kg}$ per feeding day. Calculations were based on an average body weight of $250.2 \mathrm{~kg}$ per seal and an assumed feeding rate corresponding to $7 \%$ of the body weight. In the present study the calculated average weight of 6 stomach contents from adult seals was $12.8 \mathrm{~kg}$ and the maximum $16.9 \mathrm{~kg}$, rather lower than Øritsland's (1977) average weight. Further comparison is impossible, because of the different methods of evaluation of the two studies, but these findings illustrate the need for quantitative data on the intake by seals of dominant prey organisms in different areas and seasons in order to make realistic assessments of food consumption.

In addition, more attention should probably be given to Southern Ocean food chains that do not directly involve krill, Euphausia superba, particularly as this species is sparse in many areas (Hempel 1985). Krill, unlimited food source in the seasonal pack ice zone of the East Wind Drift, is replaced by $E$. crystallorophias in the more shallow coastal waters of the permanent pack ice zone in both the Weddell Sea (Hempel 1985; Piatkowski, 
in prep.) and the Ross Sea (Marr 1962). Furthermore, $E$. crystallorophias is known to be the preferred prey of $P$. antarcticum in the Weddell Sea (Hubold 1985) and in the Ross Sea (DeWitt and Hopkins 1977). This food link is continued up to the Weddell seal, one of the top fish predators in the coastal areas of the Weddell Sea.

Acknowledgements. I would like to thank E. Drescher posthumously, for motivating and encouraging me to work on seals. Thanks are due to D. Limberger, M. Graefe, R. Dubbels, W. Arntz for the help on board $R V$ Polarstern and in the field, E. Mizdalski for identification of euphausiids, and G. Dieckmann for linguistic improvements.

\section{References}

Bertram GCL (1940) The biology of Weddell and Crabeater seals. Sci Rep Br Graham Land Exp 1:1 - 139

Castellini MA, Davis RW, Davis M, Horning M (1984) Antarctic marine life under the McMurdo Ice Shelf at White Island: a link between nutrient influx and seal population. Polar Biol 2:229-231

Clarke MR (1962) The identification of cephalopod beaks and the relationship between beak size and total body weight. Bull Br Mus Nat Hist Zool 8:419-480

Clarke MR, MacLeod N (1982) Cephalopod remains in the stomachs of eight Weddell seals. Br Antarct Surv Bull 57:33-40

Croxall JP, Prince PA, Ricketts C (1985) Relationships between prey life-cycles and the extent, nature and timing of seal and seabird predation in the Scotia Sea. In: Siegfried WR, Condy PR, Laws RM (eds) Antarctic nutrient cycles and food webs. Springer, Berlin Heidelberg New York, pp 516-533

Davis RW, Castellini MA, Horning M, Davis M, Kooyman GL (1982) Winter ecology of Weddell seals at White Island. Antarct J US $17: 183-184$

Dearborn JH (1965) Food of Weddell seals at McMurdo Sound, Antarctica. J Mammal 46:37-43
DeWitt HH, Hopkins TL (1977) Aspects of the diet of the Antarctic silverfish, Pleuragramma antarcticum. In: Llano GA (ed) Adaptations within Antarctic ecosystems. Gulf Publ, Houston, Texas, pp $557-568$

DeWitt HH, Tyler JC (1960) Fishes of the Stanford Antarctic program 1958 - 1959. Stanford Ichthyol Bull 7:162-199

Hempel G (1985) Antarctic marine food webs. In: Siegfried WR, Condy PR, Laws RM (eds) Antarctic nutrient cycles and food webs. Springer, Berlin Heidelberg New York, pp 266-270

Hubold G (1985) Stomach contents of the Antarctic silverfish Pleuragramma antarcticum from the southern and eastern Weddell Sea (Antarctica). Polar Biol 5:43-48

Hubold G, Ekau W (1985) On the midwater fish fauna of the Weddell Sea, Antarctica. Proc 5th Congr Europ Ichthyol, Stockholm 1985 (in press)

Kooyman GL (1981) Weddell seal Leptonychotes weddelli. In: Ridgway SHR, Harrison RJ (eds) Handbook of marine mammals. Academic Press, London New York Toronto, pp 275-296

Laws RM (1984) Seals. In: Laws RM (ed) Antarctic ecology, vol 2. Academic Press, London New York Toronto, pp 622-715

Lipiński M, Woyciechowski M (1981) Cephalopods in the food of Weddell seals from the Admiralty Bay (King George Island, South Shetland Islands). Pol Polar Res 2:163-167

Marr JWS (1962) The natural history and geography of the Antarctic krill (Euphausia superba). Discovery Rep 32:33-464

Murie DJ, Lavigne DM (1985) Digestion and retention of Atlantic herring otoliths in the stomachs of grey seals. In: Beddington JR, Beverton RJH, Lavigne DM (eds) Marine mammals and fisheries. Allen and Unwin, London, pp 292-299

Øritsland T (1977) Food consumption of seals in the Antarctic pack ice. In: Llano GA (ed) Adaptations within Antarctic ecosystems. Gulf Publ, Houston, Texas, pp 749-768

Stirling I (1971) Population dynamics of the Weddell seal (Leptonychotes weddelli) in McMurdo Sound, Antarctica, 1966-1968. Antarct Res Ser 18:141-163

Testa JW, Siniff DB, Ross MJ, Winter JD (1985) Weddell seal-Antarctic cod interactions in McMurdo Sound, Antarctica. In: Siegfried WR, Condy PR, Laws RM (eds) Antarctic nutrient cycles and food webs. Springer, Berlin Heidelberg New York, pp 561-565 